\title{
CIVIL LIBERTIES AND THE TRADE UNION*
}

\section{BY T. RICHARD WITMER $\dagger$}

WE usually think of the civil liberties problem, I suppose, as one of limiting the area within which the state may bring its power to bear against the individual. We do not ordinarily think of it as a matter of protecting one private person from the power of another. But it can have this aspect, too. The importance of this side of it was as well put as it ever has been by Governor Shunk of Pennsylvania ninety-five years ago. Asked by the General Assembly of the state to approve a bill to incorporate the North Branch Railroad and Coal Company, he refused. Among the reasons he gave for vetoing it was one explained thus:

"The company" contemplated by this bill, with its six thousand five hundred acres of land, and a half million of capital, will employ many men, all of them in a degree dependent upon the controlling power of the corporation. Our own history furnishes too many lamentable proofs of the fact, that power of this kind may be used, not only to exact the labor for which compensation is made, but also to circumscribe that range of thought and independence of action upon political subjects, which constitute the pride and dignity of an American freeman." 1

If in a day before there was yet a general corporation statute on the books the Governor could speak of the many "lamentable proofs" which history had already furnished, with what greater certainty could the same objection be made today? For it must be clear that in a system based, as is ours, on employment at will the power to discharge carries with it a tremendous power to interfere not only with those liberties of the employee which we call civil but even with those duties which from time to time the state exacts of him.

What remedy, for instance, does our legal system afford an employee who is discharged because he chooses to speak his mind freely on a subject obnoxious to his employer? What remedy is available if he is discriminated against because he writes a letter to the press criticizing a city administration supported by his employer? In how many of our states has he any relief if he votes the wrong way ? ${ }^{2}$ What redress can he get

* This paper, with a few inconsequential variations, was read at a meeting of the Association of American Law Schools, December 27, 1940, devoted to a symposium on civil liberties. Here, as there; it is presented more as a program for future investigation than as a report on a completed project. Though the questions that it has to ask are definite enough, the answers suggested are, even in the author's own mind, highly tentative.

† Assistant Professor of Law, Yale Law School.

1. Message of April 12, 1845, 7 PA. Arcuives (4th ser. 1902) 35, 37.

2. Compare Bell v. Faulkner, 75 S. W. (2d) 612 (11o. App. 1934) (no action for damages lies for violation of a statute making it criminal to discharge an employee "for 
if he is discharged for testifying under subpoena contrary to what his employer supposes to be his interests? If my reading of the absence of cases is correct - and on this subject does not absence of law speak more loudly than its presence? - there is none. As primitive, as elementary in our thinking as the privilege of a merchant to choose his customers, to refuse to serve for any reason or for no reason at all, is the privilege of the employer to hire and to fire for any reason or for no reason at all. We have been content, in other words, to build up sanctions against the deprivation of civil liberties by the public power of the state; we have given little thought - however commonplace be our acceptance of the notion that political democracy and unrestrained economic power are not compatible bedfellows - to the importance of providing sanctions against the use of the private power of the employer to the same end.

This privilege of hiring and firing ad libitum is, of course, being subjected to restraints today. Contract and statute alike are cutting in on it. The familiar clauses of the collective bargain that the employer will not discharge without "cause" 3 and that employees will be accorded a hearing before being fired ${ }^{4}$ are, we may be quite sure, a considerable guarantee against the sort of practices that have been mentioned. So, too, under recent statutes. Probably of greater long-run significance than the

reason of the political opinions or belief of such employee," etc.). See RowLANd, TrE Legal Protection of the Worker's Jos (1937) 94-95 for a collection of such statutes. See also Commons \& Andrews, Principles of Labor Legislation (rev. ed. 1927) 97 ("Some effort has been made to protect the employee as a voter from coercion by the employer. More than three-fourths of the states have laws which in general provide that any employer who attempts by coercion, intimidation, or threats to discharge or to lessen the remuneration of an employee to influence his vote in any election, etc., is guilty of a misdemeanor ....").

3. See Moore v. Illinois Central R. R., 112 F. (2d) 959, 966 (C. C. A. 5th, 1940), cert. granted, 61 Sup. Ct. 392 (U. S. 1940) ("The filing by an employee . . . of a suit to establish his seniority status [under a collective agreement] is not . . . a just cause to discharge him;" cf. Louisville \& N. R. R. v. Bryant, $263 \mathrm{Ky} .578,92 \mathrm{~S}$. W. (2d) 749 (1936)) ; Cross Mountain Coal Co. v. Ault, 157 Tenn. 461, 9 S. W. (2d) 692 (1928) (supporting arbitrator's finding that plaintiff was wrongfully discharged). Compare Amolette v. Dold Packing Co., 173 Misc. 477, 17 N. Y. S. (2d) 929 (Sup. Ct. 1940) ("Plaintiff's discharge was not for cause in the sense used in the contract but solely by virtue of the right vested in the employer to discontinue his business if and when he saw fit.").

4. For examples of such agreements, see Lieberaran, The Coltective Labor AgreeMENT (1939) 86 et seq., which, unfortunately, has none from the railroad industry where they appear to be most uniformly in force. A majority of our courts are willing to enforce such agreements in a suit for damages. See, e.g., Gary v. Central of Ga. Ry., 37 Ga. App. 744, 141 S. E. 819 (1928); McGlohn v. Gulf \& Ship Island R. R., 179 Miss. 396, 174 So. 250 (1937); Lyons v. St. Joseph Belt Ry., 84 S. W. (2d) 933 (Mo. App. 1935); Youmans v. Charleston \& W. C. Ry., 175 S. C. 99, 178 S. E. 671 (1933); Mansell v. Texas \& Pac. Ry., 137 S. W. (2d) 997 (Tex. Comm. App. 1940). Contra: Davis v. Davis, 197 Ind. 386, 151 N. E. 134 (1926); Louisville \& N. R. R. v. Bryant, 263 Ky. 578, 92 S. W. (2d) 749 (1.936). 
extension of federal power under the National Labor Relations Act is the reinstatement and back-pay technique that it carries with it. Though this is not quite the first time in our history that employers have been told by the legislators that there are some causes for which they may not discharge employees, ${ }^{5}$ it is the first in which an effective remedy has been given directly to the aggrieved individual. Already its vigorous enforcement, Warren Madden has told us, has brought about a considerable cessation of anti-civil liberty activity:

"As employers have come to concede the rights of their employees under this law, other troublesome problems concerning civil liberties have been eliminated or simplified in many communities. In the past, many of the asserted violations of civil liberties have occurred in industrial towns. In those towns, the question of freedom of assembly, speech, or publication, nearly always arose in connection with the attempted organization or activity of a labor union. When the principal employers in such communities have begun to obey the National Labor Relations Act and to keep their hands out of the union question, the other civil liberties problems largely disappear. The police do not interfere with assembly, speech or publication, because no one is asking them to interfere. Mfagistrates do not jail union organizers under 'disorderly conduct' or 'suspicious person' statutes or ordinances, because there is no pressure upon them to do so. And if the town is 'open' for labor union meetings, there is little likelihood of any interference with speech, press, or assembly for other purposes."

We have not yet seen the end of this development. Already Congress has followed, with surprisingly little debate, the lead of the National Labor Relations Act by requiring, in the Selective Training and Service Act of $1940,{ }^{7}$ that employers reinstate men called into military service after their term is over. ${ }^{8}$ The time may yet come when our legislatures

5. See, e.g., Poye v. State, 89 Tex. Crim. App. 182, 230 S. W. 161 (1920) (criminal prosecution for discharging employee who testified before Industrial Welfare Commission) and material cited stpra note 2.

6. Old LIBERTIES AND NEW (1939) 4 (NLRB mimeographed release No. 2169).

7. Pub. L. No. 783, 76th Cong., 3d Sess. (Sept. 16, 1940) $\$ 8(b)$.

8. Compare, however, Fair Labor Standards Act of $1938 \S 16,52$ Srar. 1069 (1938), 29 U. S. C. $\$ 216$ (Supp. 1939), which provides only for criminal proceedings against an employer who "discharge[s] or in any other manner discriminate[s] against any employee because such employee has filed any complaint or instituted or caused to be instituted any proceeding under or related to this chapter, or has testificd or is about to testify in any such proceeding, or has served or is about to serve on an industry committee." Under NLRA $\S 8,45$ StAT. 452 (1937), 29 U. S. C. $\$ 158$ (Supp. 1938), however, it is an uniair labor practice for an employer to "discharge or otherwise discriminate against an cmployee because he has filed charges or given testimony under this chapter." For practice under the Walsh-Healey Act (48 STAт. 2036 (1936), 41 U. S. C. $\$ \S 35$ ef scq. (1938 Supp.)) which makes no provision for protecting a complaining employee either directly 
will consider more broadly the task of formulating the circumstances under which employers will not be allowed to discriminate against their employees.

Meanwhile the beginnings of a new system are visible. Job control is passing from employer to union. For the most part, in contests between union and member, the courts are supporting the former's claim of at1thority to make general rules determinative of who shall and who shall not be employed. ${ }^{9}$ The further this development progresses the more important it will be to ask the same questions about the union that we have already asked about the employer. But our asking them raises a nice problem in political administration, a problem of balancing against each other the interests of two groups - state and union - with claims on common members. It is a problem to which, so far, little consideration has been given. Among the political philosophers, even such a pluralist as Laski ${ }^{10}$ seems not to have paid much attention to it. For the lawyer it is, of course, in some of its aspects, a considerably easier problem to handle than is that of employer-employee relations. Passing from the latter field to that of union-member relations, he not only avoids the diffculties with which specific enforcement of personal relations or computation of damages for breach of an at-will relation is surrounded, for example, but he jumps from a starting premise in the one case of freeto-discharge-except-under-specified-conditions to that of not-free-to-discipline-except-under-specified-conditions in the other. ${ }^{11}$ (It should be added, of course, that this last remark is not applicable to a case in which the

or through criminal sanctions against the employer, see ATT'Y GEN's CoMM. oN ADMINistrative Procedure, The Walsh-Healey Act (mimeographed ed. 1940) 16-17.

9. See, for examples, Minasian v. Osborne, 210 Mass. 250, 96 N. E. 1036 (1911); Ryan v. Hayes, 243 Mass. 168, 137 N. E. 344 (1922) ; Hartley v. Brotherhood of Ry. \& Steamship Clerks, 283 Mich. 201, 277 N. W. 885 (1938); O'Keefe v. Local 463, 277 N. Y. 300,14 N. E. (2d) 77 (1938); Evans v. National Union of Printing Workers [1938] 4 All E. R. 51 (K. B.). Compare Piercy v. Louisville \& N. Ry., $198 \mathrm{Ky}, 477,248$ S. W. 1042 (1923); Sullivan v. Barrows, 21 N. E. (2d) 275 (Mass. 1939); Cameron v. International Alliance of Theatrical Stage Employees, 118 N. J. Eq. 11, 176 Atl. 692 (1935).

10. His A Grammar of Politics (1925), though not adequately specific, is, however, suggestive in many places. See also Milne-Bailey, Trade Unyons AND tine State (1934); 1 Telrer, The Law Governing Labor Disputes and Collective Bargaining

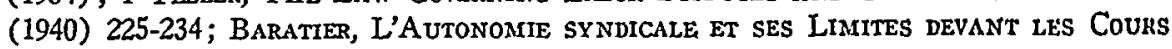
AngLAises (1928).

11. Otto v. Journeymen Tailors' Union, 75 Cal. 308, 17 Pac. 217 (1888); Polin v. Kaplan, 257 N. Y. 277,177 N. E. 833 (1931); Luby v. Warwickshire Miners' Ass'n [1912] 2 Ch. 371; Clarke v. Ferrie [1926] N. I. 1 (Ch.); cf. Clark v. Morgan, 271 Mass. 164,171 N. E. 278 (1930) ("It is true the particular offense charged against the plaintiff is not specifically prohibited . . . [But the plaintiff] testified that he knew no member should work on a job on which there was a strike and he admitted that, according to the well known custom, it violated the constitution to work under such conditions if known ..."). 
union's action is that of refusing membership to an applicant. ${ }^{12}$ Here the rule of delectus personarum prevails. ${ }^{13}$ Except in New York where denial of membership on account of race, color or creed has been made a misdemeanor, ${ }^{14}$ the furthest that English-speaking legislatures ${ }^{15}$ or courts ${ }^{16}$ have gone has been to put indirect pressure on the unions to keep their doors open).

If we look at a few of the instances of possible conflict, the prublem in general may be somewhat clearer. No matter how pluralistically inclined we may be, it is not likely, for example, that we shall expect our

12. See Wolfe, Adarission to Amrerican Trade Unions (1912) on the subject in general.

13. Mayer v. Journeymen Stonecutters' Ass'n, 47 N. J. Eq. 519, 20 Atl. 492 (Ch. $1890)$, to the effect that there is no power in the courts to compel an unineorporated association to admit to membership, is still good common law. See, in accord, Mraguire v. Buckley, 17 N. E. (2d) 170 (Miass. 1938) ; Frank v. National Alliance of Bill Posters, 89 N. J. L. 380, 99 Atl. 134 (Sup. Ct. 1916) ; Sinous v. Berry, 210 App. Div. 90, 205 N. Y. Supp. 442 (1st Dep't 1924); Miller v. Ruehl, 166 MIisc. 479, 2 N. Y. S. (2d) 394 (Sup. Ct. 1938).

14. Laws of 1940 , c. 9, p. 19. See Comment (1940) 53 Harv. L. Rev. 1215; Comment (1939) 39 COL. L. REv. 986, 995.

15. Australia bars the benefits of being a registered union to any organization which "imposes unreasonable conditions . . . upon any applicant for membership" or does not "provide reasonable facilities for the admission of new members . . .," Commonwealth Conciliation and Arbitration Act, 1904-1934, $\$ \$ 5 D(1)(d), 60(1)(d) ; 1$ Cosrsos:weastr Acts, 1901-1935, 157, 159; see Mlarine Cooks, Bakers \& Butchers Ass'n, Ex parte Snell, 27 C. A. R. 43 (1928) ("such a high entrance fee as \pm 10 can only be taken as imposed for the purpose of unduly restricting membership"). In Nev Zealand a union is limited to an entrance fee of five shillings if it wishes to be registered under the Act [Industrial Conciliation and Arbitration Act, 1925, §143, as amended by Acts, 1936, No. 6, §28; 3 Public Acts, 1908-1931 (Reprint) 1005, Butrerwortris Amr. Punlrc Acrs (Supp. No. 11, 1939) 78]; see Federated Seamen's Union v. Sanford [1930] N. Z. L. R. 460, 464. Under Pennsylvania Labor Relations Act $\$ 6(1)(c)$, PA. STAr. Aszr. (Purdon, Supp. 1910) tit. $43 \$ 211.6(1)$ (c), any labor organization which excludes "by" ritualistic practice, constitutional or by-law proscription, by tacit agreement among its members, or otherwise . . . a person or persons [from] membership . . . on account of race, creed or color" or denies "membership to a person or persons who are employees of the employer at the time of the making of such agreement" cannot have whatever benefit the Act gives by way of validating a closed-shop contract. Similarly, under the Wisconsin Labor Relations Act, WIs. STAT. (1939) $\$ 111.06(1)(c)$, the Board is directed to "declare any ... all-union agreement terminated whenever it finds that the labor organization involved has unreasonably refused to receive as a member any employee" of the employer with whom it was made. The Pennsylvania and Wisconsin Acts are noted in (1940) 53 Harv. L. Rev. 500.

16. A result similar to that of the Pennsylvania and Wisconsin Acts, stopra note 15, has been reached by judicial decision in New Jersey [IWilson v. Newspaper \& Mail Deliverers' Union, 123 N. J. Eq. 347, 197 Atl. 720 (Ch. 1938)] and adopted in 4 RestATEnent, ToRts (1939) §810. See Despres, The Collective Agreement for the Union Shop (1939) 7 U. of ChI. L. Rev. 24, 34; (1940) 49 YaLE L. J. 754; cf. Warm, A Situdy of the Judicial Attitude Toward Trade Unions and Labor Legislation (1939) 23 Min:3i. L. REv. 255, 293. 
courts to allow a union member to be penalized for doing that which the state commands him to do. Nor do the results in the courts disappoint our expectations. The union member's obeying a subpoena and testifying truly before a court or commission ${ }^{17}$ his playing with nonunion musicians contrary to the rule of the union when called on, as a member of an army band, to do so ${ }^{18}$ his refusing to follow the instructions of his fellow-unionists when he is acting as a member of a local plumbing inspection board ${ }^{10}$ - none of these, the courts tell us, is justification for imposing discipline upon him.

What shall be the result if we move from the field of duty to that of privilege? Shall it be said that the union, being a voluntary association, is free to set for its members such standards of public conduct as it sees fit? That it may, for example, if it so chooses, forbid its members to break discipline by petitioning the legislature to repeal a statute supported by the officials of the organization? ${ }^{20}$ That it may set up political tests for its membership?21 That it may punish those who institute litigation against it or its friends ?22 That it may dictate the way in which its members shall vote for bargaining representatives in an election held under one of our labor relations acts ? $^{23}$

The problem, obviously, is a broad and complicated one. Probably at this stage of the game it would be unwise to venture more than a few remarks that indicate the directions in which we shall have to look for a solution. It seems quite proper, in the first place, to inquire into what is involved in expulsion from the union. ${ }^{24}$ For we must not forget that

17. St. Louis S. W. Ry. v. Thompson, 102 Tex. 89, 113 S. W. 144 (1908); Angrisani v. Stearn, 167 Misc. 731, 3 N. Y. S. (2d) 701 (Sup. Ct. 1938), aff'd, 255 App. Div. 975, 8 N. Y. S. (2d) 997 (2d Dep't 1938) ; cf. Abdon v. Wallace, 95 Ind. App. 604, 165 N. E. 68 (1929).

18. Parker v. Toronto Musical Prot. Ass'n, 32 Ont. 305 (C. P. 1900).

19. Schneider v. Local 60, 116 La. 270, 40 So. 700 (1905).

20. Compare Spayd v. Ringing Rock Lodge, 270 Pa. 67, 113 Atl. 70 (1921).

21. Compare Shein v. Rose, 12 N. Y. S. (2d) 87 (Sup. Ct. 1939) (refusal to admit alleged Communist to full membership sustained); Judge v. Transport \& General Workers Union, summarized in [1937-1938] INT. SURVEY OF LEGAL. DeCISIONS ON LABOUR LAW 17 from London Times, Dec. 11, 1937 (Ch.) (expulsion of Fascist enjoined for want of union rule covering the matter). Compare Harmon v. United Mine Workers, 166 Ark. 255, 266 S. W. 84, 1119 (1924) (procuring discharge of union member expelled for joining the Ku Klux Klan states no cause of action).

22. Compare Thompson v. Brotherhood of Locomotive Engineers, 41 Tex. Civ. App. 176, 91 S. W. 834 (1905); Burke v. Monumental Division, No. 52, 273 Fed. 707 (D. Md. 1919), 286 Fed. 949 (D. Md. 1922), aff'd, 298 Fed. 1019 (C. C. A. 4th, 1924), rev'd and bill dismissed for want of federal jurisdiction, 270 U. S. 629 (1926); cases cited note 34 infra,

23. Compare Ray v. Brotherhood of R. R. Trainmen, 182 Wash. 39, 44 P. (2d) 787 (1935).

24. I speak particularly of expulsion, for it and job-interference are the matters most often litigated in the reported cases. But many of the remarks that are made about 
the union's functions vary. It may be merely a fighting and bargaining organization. It may add to this the character of an insurance society. It may, where closed-shop contracts prevail, become a job-dispensing association with complete control over the work-market. How much of the pressure that arises from these interests the union shall be allowed to bring to bear on the member in any particular instance is a question of importance which can hardly be answered in an a priori manner. We may in many cases be willing to see the recalcitrant member expelled from the bargaining organization ${ }^{25}$ where we should object to his being deprived of an accustomed livelihood. We may, in other instances, conclude that even the pressure of expulsion alone ought not to be permitted. And we may quite often believe that the union should be free to impose whatever discipline it chooses.

We must inquire, in the second place, into the relevance, in determining a case of the sort we are interested in, of the standards set by the Bill of Rights for the state's own conduct. It would, of course, be going too far to say that its spirit is so all-pervasive that no association may, by rule or discipline, keep its members from the free exercise of any privilege which is mentioned in it. We do not expect the same religious tolerance of the United Presbyterian Church that we expect of the state. We do not expect the same political tolerance of the Sixth Ward Republican Club that we expect of the state. But, equally, it would be going too far to say that the Bill of Rights is exclusively a state concern, that it has no part to play in determining the legality or illegality of conduct on the part of individuals and associations. Whether we take the approach of the courts in the expulsion cases and, arguing along contract lines, say that an association's rules which are contrary to public policy are void ${ }^{25}$ or accept the rule of the Restatement which forbids the union to interfere with the job possibilities of workers excluded from the union unless their exclusion is on "reasonable" grounds, ${ }^{27}$ we can hardly avoid giving consideration to the standards set up by the Bill of Rights.

it will be equally applicable to other forms of discipline-fines and loss of office, for instance-occasionally encountered in the cases and frequently employed by unions.

25. I do not mean by this, of course, that it is not of importance for a worker to have bargaining representation. Compare National Fed. of Ry. Workers v. National Mediation Board, 110 F. (2d) 529, 537-538 (App. D. C. 1940), cert. denicd, 310 U. S. 628 (1940). But its importance must not be overrated since, as is the case, the non-union worker is entitled to the fruits of whatever bargain is made. Gregg v. Starles, $185 \mathrm{Ky}$. 834, 224 S. W. 459 (1920); Yazoo \& Miss. Valley R. R. v. Sideboard, 161 Mliss. 4, 133 So. 669 (1931); see Yazoo \& Miss. Valley R. R. v. Webb, 64 F. (2d) 902, 904 (C. C. A. 5th, 1933); cf. Rowlett v. Louisville \& N. R. R., 255 Ky. 691, 75 S. W. (2d) 371 (1934).

26. As, for example, in Schneider v. Local 60, supra note 19; Cameron v. International Alliance of Theatrical Stage Employees, supra note 9.

27. 4 Restatearent, ToRTs (1939) $\$ 810$ : "Workers who in concert procure the dismissal of an employee because he is not a member of a labor union satisfactory to the workers are . . liable to the employee if, but only if, he desires to be a member of the labor union but membership is not open to him on reasonable terms." 
In the third place we must ask about the relative importance of state and union when their claims of freedom and of discipline are in conflict. That both are important, we need not doubt. The issue is not one which can be satisfactorily resolved by asserting that one is more sacred thatn the other, that a claim on behalf of freedom by the state is entitled to more respect than a claim of discipline on the part of the union or vice versa. If we remind ourselves with Laski that the inevitability of the state does not entitle it to "moral pre-eminence of any kind," 28 we must also remind ourselves with John Dewey that "There is no more an inherent sanctity in a church, trade-union, business corporation, or family institution than there is in the state." ${ }^{29}$ The result is the necessity of assessing the worth of the jobs the organizations in question are doing and the importance of freedom and discipline to the accomplishment of those jobs. This is not an easy task. But the chances are strong, it would seem, that as the democratic state becomes more and more "positive" that is, as it engages more and more energetically in the business of supervising the economic system - it will more and more need all the advice and criticism that it can get. It will need this advice and criticism not only from organizations but from those organizations' members, for its officials will need to know at first-hand how representative of their members the official spokesmen for the organizations are. The implicaltion of all this would seem to be that the state will be entitled to break down whatever barriers stand in the way of the members' access to its officials and legislators - that, in other words, to this extent at least, it will be entitled to enforce the guarantees of free speech, free petition and free assembly against organizations which might otherwise deny them.

In the realm of political activity, however, the solution does not seem to be quite so clear. Of course, if we could discover the proper functions of the trade union in as simple a manner as did the House of Lords in 1909 when it ruled that the promotion of a political party was not among them, ${ }^{30}$ there would be little difficulty. If we could accept the orthodox limits of trade union activity as the proper limits, we would not have to discuss the matter mucl further. The claim for a union's rejecting political tests has been put in strong language by a left-wing writer: ${ }^{01}$

28. LASKI, op. cit. supra note 10 , at 88 .

29. The Public and Its Problens (1927) 74.

30. Amalgamated Society of Ry. Servants v. Osborne [1910] A. C. 87 (brilliantly criticized in WEBB \& WEBB, THE HISTORY OF TRADE UNIONISM (rev. ed. 1920) 608-631). The effect of the judgment on political action was corrected by The Trade Union Act, 1913, 2 \& 3 Gro. 5, c. 30. Compare The Trade Disputes and Trade Unions Act, 1927, 17 $\& 18$ GEO. 5, c. $22, \S 4$.

31. Wolfe, What Is The Communist Opposition? (2d ed. 1933) 19. It is only fair to say that the author of this pamphlet, written during the Trade Union Unity League period of the Communist party, is here criticizing the party for taking its mem- 
"What are the trade unions? The unions are the most elementary, the broadest mass organizations of the working class. . . . They should include all workers regardless of creed, color, sex, age, occupation, or political belief. The acid-test of the soundness of a union organization is its functioning in a strike struggle. When a strike begins, we do not ask a worker: 'Are you Catholic, Jew or Protestant? Are you a Republican, Democrat or Socialist? Are you Fascist or Ku Klux Klanner? If so you can't go out on strike with us.'

"On the contrary, we say to Fascist or Ku Kluxer or Tammany voter: You work in the same shop. You have the same interests. You suffer the same conditions, wage-cuts, long hours. You have the same enemy, the same boss. Therefore you must come out with us!'

"Obviously, then, a union is not a political party. It must not exclude, but include. . . . It must seek to include all who toil, all who recognize the elementary fact that in questions of hours, wages and working conditions, there is a conflict of interest between bosses and workers."

Our problem, of course, is whether the courts, speaking for the state, should require the unions to do what the trade unionist may urge them to do. Shall the courts say that, however indistinct it may be, a line of demarcation between political activity and proper trade union activity must be found? It is doubtful whether the union can content itself for long with no broader questions than those of wages, hours and working conditions in the single shop or even the single industry. Shall the courts say that it must? The ramifications even of these orthodox demands are wide. The coal miners, for instance, apparently find it quite necessary to intervene in public service commission hearings so that the claims of coal to protection from the competition of gas, electricity and oil shall be heard from their point of view. ${ }^{32}$ This reaches far into the economic polity of the state. Shall the courts deny that it is a proper function of the United Mine Workers? So, too, we may suppose that the railway unions have a larger interest in the governance of their employers than would be connoted by the orthodox definition of a union. Shall the courts deny that this is so? The advancement of economic democracy, if I may put it this way, may call for action on the political front. Trade union discipline may call, at least sometimes, for adherence to a political program. A departure from this program at the polls may be as serious an offense as is crossing a picket line. Shall the courts forbid punishment of the offender?

bers out of the main current of the American labor movement by organizing separate unions for them.

32. See, e.g., Pennsylvania Power \& Light Co. v. Public Serv. Cumm., 112 Pa. Super. 500, 171 Atl. 412 (1934); Illinois Coal Operators' Ass'n v. Peoples Gas Light \& Coke Co., 7 P. U. R. (N.S.) 403 (Ill. Commerce Comm. 1934). 
Perhaps the questions are not yet ripe for asking. But if they are, and when they are, it is not likely that much help will be found in what little public discussion of the matter we have had thus far. The circumstances have not been favorable for clear thinking. We have been concerned thus far largely with the attitude of unions towards supposed or real Communists. At a time when the unions themselves are hardly less conservative than the rest of society on this issue, ${ }^{33}$ it is too much to expect any effective intervention by the legislatures or the courts on behalf of the minority group. Such lack of expectation, of course, is no guide to what may be looked for when the issue moves from the permissibility of the unions' excluding the adherents of a group as distasteful to them as they are to those who administer the law to the permissibility of their laying down a political program to which all members, present and prospective, are required to adhere. That requires, to repeat, a far more intelligent and sustained discussion than we have yet had.

But if we have some doubts one way or the other about the answers to the questions that have so far been suggested, we ought, probably, to have very few on some others. Freedom of litigation, for instance, is hardly so essential a part of the democratic process that the courts should be asked to strike down all hindrances to its pursuit. The courts are as wise, to take an example of this, in adhering to the general requirement that all available remedies within the union be exhausted before redress is sought before them ${ }^{34}$ as they are unwise in many of the exceptions they have grafted upon this rule. ${ }^{35}$ Similarly, the importance

33. For accounts of trade union-Communist relations in the 1920's, see BrMBA, History of The American Working Class (2d ed. 1933) 308-312, 338-349; Perlasan and Taft, Labor Movenrents (vol. 4 of History of Labor in the United States) (1935) 538-561; Schneider, The Workers' (Communist) Party and Amertcan Trade Unrons (1928).

34. Norfolk \& Western Ry. v. Harris, 260 Ky. 132, 84 S. W. (2d) 69 (1935) (scniority) ; Agrippino v. Perrotti, 270 Mass. 55, 169 N. E. 793 (1930) (local autonomy as to dues); Snay v. Lovely, 276 Mass. 159, 176 N. E. 791 (1931) (expulsion); Webb v. Chicago, R. I. \& P. Ry., 136 S. W. (2d) 245 (Tex. Civ. App. 1940) (seniority).

35. Exceptions to the rule are chiefly allowed under these circumstances: (1) When the union tribunal had no jurisdiction over the contest. Rueb v. Rehder, 24 N. M. 534, 174 Pac. 992 (1918) ; Gersh v. Ross, 238 App. Div. 552, 265 N. Y. Supp. 459 (1st Dep't 1933). Contra: Harris v. Detroit Typographical Union, 144 Mich. 422,108 N. W. 362 (1906) ; Hickey v. Baine, 195 Mass. 446, 81 N. E. 201 (1907); Clark v. Morgan, 271 Mass. 164,171 N. E. 278 (1930). (2) When there were serious procedural irregularitics before the tribunal. Johnson v. United Brotherhood of Carpenters, 52 Nev. 400, 288 Pac. 170 (1930); Lo Bianco v. Cushing, 117 N. J. Eg. 593, 177 Atl. 102 (Ch. 1935), aff'd, 119 N. J. Eq. 377, 182 Atl. 874 (1936) ; Rodier v. Huddell, 232 App. Div. 531, 250 N. Y. Supp. 336 (1st Dep't 1931). Contra: Bonham v. Brotherhood of R. R. Trainmen, 146 Ark. 117, 225 S. W. 335 (1920); Screwmen's Benevolent Ass'n v. Benson, 76 Tex. $552,13 \mathrm{~S}$. W. $379(1890)$. (3) When the action is for damages rather than reinstatement. Brotherhood of Locomotive Engineers v. Green, 210 Ala. 496, 98 So. 569 (1923); St. Louis S. W. Ry. v. Thompson, 102 Tex. 89, 99, 113 S. W. 144 (1908). (4) When the union's substantive rule in question is contrary to public policy. Cameron v. International 
of freedom from coercion by the employer in the choice of a bargaining representative at a labor board election can only with difficulty be thought of as implying a duty on the union's part not to discipline its members if they choose to put another organization ahead of their own. The very existence of the union will often depend on its being able to do so, and on its existence depend most of the items - insurance benefits, an interest in the union's assets, and the like - on which equitable relief, at least, usually hinges. More important, far more important, is it that the member who is thus required to stand by his union at such an election shall, along with his fellows, have a voice, directly or indirectly, in the making of whatever bargain is to be made.

This means, if the proposition is broadened a bit, that not only here but in a great many other questions which arise as to the relation between the state, the union, and the member, the responsiveness of the union to the member must be looked into before we decide on state intervention on his behalf or the contrary. (I put the matter in terms of "responsive-

Alliance of Theatrical Stage Employees, 118 N. J. Eq. 11, 20, 176 Atl. 692, 697 (1935); Ray v. Brotherhood of R. R. Trainmen, 182 Wash. 39, 44 P. (2d) 787 (1935). (5) When the remedy within the organization is remote or indefinite. Harris v. Geier, 112 N. J. Eq. 99, 164 Atl. 50 (Ch. 1932); Local 104 v. International Brotherhood of Boiler Malsers, 158 Wash. 480, 291 Pac. 328 (1930) ; of. Fish v. Huddell, 51 F. (2d) 319 (App. D. C. 1931) ; Snay v. Lovely, 276 Mass. 159, 176 N. E. 791 (1931).

If the reason for the general requirement that remedies within the organization be exhausted before coming to court is to minimize outside interference with the normal workings of the organization and to give it an opportunity for self-correction of errors, if it is to mitigate damages and to avoid litigation expenses wherever possible, if it is to allow the union, by developing its own interpretation of its rules, to achieve a uniformity in application that cannot be achieved through the courts [cf. Mfoore v. Illinois Central R. R., 112 F. (2d) 959 (1940), cert. granted, 61 Sup. Ct. 392 (1940); Norfolls \& W. Ry. v. Harris, $260 \mathrm{Ky} .132,84$ S. W. (2d) 69 (1935)], then many of the exceptions just noted ought not to prevail. The rule should be that all errors for which a corrective device is provided by the union and which are not highly unlikely to be corrected through this device must go through these channels. This is not to say that there is no room afterwards for an award of damages if, as is often the case [Brotherhood of Locomotive Engineers v. Green, 210 Ala. 496, 499, 98 So. 569, 572 (1923), app. dismisscd, 265 U. S. 576 (1924) ; Blanchard v. Newark Joint District Council, 77 N. J. L. 389, 71 Atl. 1131 (Sup. Ct. 1909), aff'd, 78 N. J. L. 737, 76 Atl. 1087 (1910). But of. Stivers v. Blethen, 124 Wash. 473, 215 Pac. 7 (1923); Robinson v. Dahm, 94 Arisc. 729, 734, 159 N. Y. Supp. 1053,1056 (Sup. Ct. 1916)], reversal by an appellate union tribunal leaves the plaintiff without satisfaction for loss incurred in the meantime. Nor is it to say that there is no room at all for court action in the meantime. But this action should be confined, as it was in Powell v. United Ass'n of Plumbers, 240 N. Y. 616, 148 N. E. 728 (1925), to the furnishing of a supersedeas device until internal remedies are exhausted. Even the argument of futility, sound as it is, [Barbrick v. Huddell, 245 Nass. 428, 139 N. E. 629 (1923); Heasley v. Operative Plasterers Int. Ass'n, 324 Pa. 257, 188 Atl. 205 (1936); cf. Mfulcahy v. Huddell, 272 Mass. 539, 172 N. E. 796 (1930)] could probably be better handled in this way than otherwise in view of the ease with which futility can be alleged and made to seem probable. 
ness" rather than of "the civil liberties of the members inside of the organization" because the latter might seem too bold an offer to intervention by strangers.) This, I suggest, is a fourth factor that must go into the making of any judgment as to the proper solution of the more general question - the question, that is, of how far the union can go in restricting the privileges of its members in the community at large - that has already been suggested.

The greater the power the union has - the greater, that is, the number of restrictions it can legitimately place on its members outside of its walls - the more important it is that the essentials of democratic procedure within its walls be observed. Conversely, the less these essentials are observed the more reason there is to limit the area of the organization's power over its membership.

It will not do, of course, for the state to examine the workings of unions on their legislative and their treaty-making sides with the meticulousness with which it supervises their judicial processes. But the two are of much the same order. Few are the issues of procedural due process, for instance, that have not been raised where a union's judgment has been attacked in court. Notice and hearing, ${ }^{38}$ specificity of charges, ${ }^{87}$ the

36. Some courts, treating these requirements as a normal rule, impose them in the absence of provisions to the contrary in the organization's constitution or by-laws or use them as a standard when construing inexplicit provisions of the organization's rulcs. Gardner v. Newbert, 74 Ind. App. 183, 128 N. E. 704 (1920) ; Steinert v. United Brotherhood of Carpenters, 91 Minn. 189, 97 N. W. 668 (1903) ; Cotton Jammers \& Longshoremen's Ass'n v. Taylor, 23 Tex. Civ. App. 367, 56 S. W. 553 (1900); Riverside Lodge No. 164 v. Amalgamated Ass'n of Iron Workers, 13 F. Supp. 873 (W. D. Pa. 1935); Burn v. National Amal. Labourers' Union [1920] 2 Ch. 364. Others hold that discipline without notice and hearing is so contrary to public policy that even a specific rule to the contrary will not be tolerated. Swaine v. Miller, 72 Mo. App. 446 (1897); Gilmore v. Palmer, 109 Misc. 552, 179 N. Y. Supp. 1 (Sup. Ct. 1919); Bricklayers' Union v. Bowen, 183 N. Y. Supp. 855 (Sup. Ct. 1920), aff'd, 198 App. Div. 967, 189 N. Y. Supp. 938 (4th Dep't 1921); see Blek v. Kirkman, 148 Misc. 522, 266 N. Y. Supp. 91 (Sup. Ct. 1933), rev'd, 242 App. Div. 815, 275 N. Y. Supp. 645 (1st Dep't 1934). But see People ex rel. Schults v. Love, 199 App. Div. 815, 817, 192 N. Y. Supp. 354 (1st Dep't 1922) ("This being a voluntary unincorporated association, it was entirely competent for the union to provide, as was here provided, for a suspension or expulsion of a member by summary action and without formal trial . . ."). Contra: Brown v. Lehman, 15 A. (2d) 513 ( $\mathrm{Pa}$. Super. Ct. 1940). In the second case, the rule of the Pennsylvania court makes more sense than that of the lower New York courts, but adoption of it, of course, leaves the court free to inquire into the merits of the disciplinary action taken where it would not otherwise be free to do so. The same remark is applicable to other matters essential to the fair trial of an issue of fact or to the fair determination of the meaning of a union rule. In other words, apart from the question whether or not the union has followed the procedure which it has prescribed for itself, the questions before the court should be (1) whether that procedure is such as is likely to yield a just result and (2) in the absence, but only in the absence, of such a procedure, what the truth of the fact or the proper construction of the rule in dispute is.

37. Johnson v. Brotherhood of Carpenters, 52 Nev. 400, 288 Pac. 170 (1930). 
substantialness of the evidence, ${ }^{38}$ confrontation of witnesses, ${ }^{30}$ double jeopardy, ${ }^{40}$ bias on the tribunal's part ${ }^{41}$ - all of these and many more have been the subjects of examination. This civil liberty at least is well supervised from the outside. Such supervision, of course, is not an essential part of state-union relations. The courts, ignoring the internal procedures of the union completely, could determine de noz'o the issue before the union tribunal - whether the member committed the act with which he was charged, for instance - and allow or disallow ouster accordingly. They could, if they so chose, both do this and require that procedural safeguards be observed inside of the union. But what they could hardly do decently is to give finality to the union's judgments and at the same time refuse to pass upon the adequacy of the trial before the union tribunal. Whether the case before the union lies on its criminal side - c.g., the disciplining of a member for disobedience to the union's law ${ }^{42}$ - or on its civil side - e.g., a dispute as to the proper interpretation of a seniority clause in a collective bargain ${ }^{43}$ - it is this goal of finality that many of

38. Koukly v. Canavan, 154 Misc. 343, 277 N. Y. Supp. 28 (Sup. Ct. 1935) ; IVeiss v. Musical Mut. Prot. Union, 189 Pa. 446, 42 Atl. 118 (1899).

39. See Koukly v. Weber, 154 Misc. 659, 661-2, 277 N. Y. Supp. 39, 42 (Sup. Ct. 1935). Compare, as to the privilege of the proposed disciplinee to be present throughout the proceedings, Fales v. Miusicians' Prot. Union, 40 R. I. 34, 99 Atl. 823 (1917); Ross v. Electrical Trades Union, 81 Sol. J. 650 (Ch. 1937).

40. With Rueb v. Rehder, 24 N. 3f. 534, 174 Pac. 992 (1918), compare Simpson v. Brotherhood of Locomotive Engineers, 83 W. Va. 355, 376, 98 S. E. 580, 585 (1919), cert. denied, 250 U. S. 644 (1919) ; Burke v. Monumental Division No. 52, 286 Fed. 949 (D. Md. 1922), aff'd, 298 Fed. 1019 (C. C. A. 4th, 1924), dismissed for ztant of federal jurisdiction, 270 U. S. 629 (1926).

41. With Gaestel v. Brotherhood of Painters, 120 N. J. Eq. 358, 185 Atl. 36 (Ch. 1936) ; Koukly v. Canavan, 154 Misc 343, 277 N. Y. Supp. 28 (Sup. Ct. 1935); Weiss v. Míusical Miut. Prot. Union, $189 \mathrm{~Pa}$. 446, 42 Atl. 118 (1899); Loeal 7, Bricliayers' Union v. Bowen, 278 Fed. 271, 278 (S. D. Tex. 1922), compare Maclean v. Workers' Union [1929] $1 \mathrm{Ch}$. 602 (includes strong criticism of the "natural justice" doctrine); Hall v. Morrin, 293 S. W. 435 (Mo. App. 1927).

42. MicConville v. Milk Wagon Drivers' Union, 106 Cal. App. 696, 289 Pac. 852 (1930) ; Elfer v. Marine Engineers Benef. Ass'n, 179 La. 383, 154 So. 32 (1934); Shinshy v. Tracey, 226 Mass. 21, 114 N. E. 957 (1917); Simpson v. Brotherhood of Locomotive Engineers, 83 W. Va. 355, 98 S. E. 580 (1919), cert. denied, 250 U. S. 644 (1919). See Snay v. Lovely, 276 Mass. 159, 163, 176 N. E. 791,792 (1931). How far these and similar cases will carry when the question is one of the construction of the union's substantive rules covering offenses is not at all clear in view of the rule-see the cases cited supro note 11-that the union may punish only for offenses specified in its constitution and bylaws. Compare, in Burke v. Monumental Division No. 52, 273 Fed. 707 (D. MId. 1919), the scope of judicial review accorded to the claim of wrong venue within the union with that given the claim of no cause of action under union law.

43. Shaup v. Brotherhood of Locomotive Engineers, 223 Ala. 202, 135 So. 327 (1931) ; Evans v. Johnston, 300 Ill. App. 78, 20 N. E. (2d) 841 (1939), ccrt. denied, 309 U. S. 662 (1940); Ryan v. New York C. R. R., 267 Mich. 202, 255 N. W. 365 (1934) ; Franklin v. Pennsylvania-Reading Seashore Lines, 122 N. J. Eq. 205, 193 Atl. 712 (Ch. 1937) ; Brotherhood of R. R. Trainmen v. Price, 108 S. W. (2d) 239 (Tex. 
our courts avowedly pursue. ${ }^{44}$ It is the acceptance of this goal that dictates the road which precedes it.

But just as finality can decently be given the union's judgment only if safeguards have been erected along the way, so the liberality of the state towards the union's legislation ought to depend in large measure on the availability of modes of redress within the union. The individual member can better be asked to forego appeal to the state for help if it is certain that his voice will be heard within the organization than otherwise. The difficulty is, of course, that we have no such set norms for -democratic procedure as we have for judicial. Within the state itself we are constantly experimenting. The town meeting and representative assemblies, the long ballot and the increase in appointed officers, the initiative and referendum and the limitation of the number of times a constitutional amendment can be proposed within a given period - all of these are competitors with each other for making a workable system. So in the union: the extent to which popular control of the executive shall go, whether the collective bargain shall be negotiated by a small committee behind closed doors or in full sight of the membership as the American Newspaper Guild advocates in its "goldfish bowl" policy, how much local autonomy there shall be and how much central control, whether the initiative and referendum are usable or not - all of these are open questions. They must be so as long as unions are confronted with problems diverse as they face today. And as those problems change, as the union's functions vary, the answers to these questions will vary, too. It would be presumptuous, under these circumstances, for the state to say with much particularity where, to use the Webbs' phrase, "the long and inarticulate struggle of unlettered men to solve the problem of how to

Civ. App. 1937). The qualifications employed by the courts in these cases to indicate where the rule of finality stops vary: "construction of the rules . . . upon a matter as to which an honest difference of opinion may well appear to exist"; "mere difference of opinion between two contending bodies of men"; not "arbitrary or unjust, or an unreasonable interpretation of the Order's statutes, constitution or custom"; "no evidence of fraud, oppression or bad faith" are some of the phrases they use. With the cascs just cited, compare Shadley v. Brotherhood of R. R. Trainmen, 212 Mo. App. 653, 254 S. W. 363 (1923); Robinson v. Dahm, 94 Misc. 729, 159 N. Y. Supp. 1053 (Sup. Ct. 1916); Gleason v. Thomas, 117 W. Va. 550, 186 S. E. 304 (1936).

44. For discussions of finality on other subjects, consult Brotherhood of R. R. Trainmen v. Barnhill, 214 Ala. 565, 108 So. 456 (1926) (discontinuance of strike benefits); Durkin v. Brotherhood of Locomotive Firemen, 170 Md. 562, 185 Atl. 322 (1936) (insurance); Maloney v. District 1, United Mine Workers, 308 Pa. 251, 162 Atl. 225 (1932) (election nomination procedure); International Hod Carriers, Local 426 v. International Hod Carriers, Local 502, 101 N. J. Eq. 474, 138 Atl. 532 (Ch. 1927) (chartering of locals); Pratt v. Amalgamated Ass'n of Street Ry. Employees, 50 Utah 472, 167 Pac. 830 (1917) (rules governing issuance of withdrawal and transfer cards); Stivers v. Blethen, 124 Wash. 473, 215 Pac. 7 (1923) ; Harris v. Missouri P. R. R., 1 F. Supp. 946 (E. D. Ill. 1931) (appellate procedure); cf. McNichols v. International Typographical Union, 21 F. (2d) 497 (C. C. A. 7th, 1927) (constitutional amendment procedure). 
combine administrative efficiency with popular control" 45 shall end. It is not so presumptuous for its courts to say that this is a matter which they will take into consideration in deciding how broad the allowable area of union control over its members' activities is. To do this job well requires far more knowledge than we now have of how, in fact, the unions operate internally. To accumulate this knowledge will require a generation of careful observation and research. To interpret it will require the niceness of a Mansfield's, a Cardozo's, judgment. Both have still to be sought for. In the meantime, all judgments must be tentative and the preaching of democracy in the voluntary association that we call the trade union as well as in that compulsory society which we call the state has got to go on.

45. Industrial Democracy (1920 ed.) 58. Lerner, Democracy tuilh a Union Card (1938) in IDEAs ARE WeApoNs (1939) 517, 528, also puts the matter neatly: "The present movement to impose labor discipline from without is based on a tragically false premise. The premise is that you can produce either responsibility or democracy by fiat. Trade unions can be successfully regulated only when they have already achieved their basic objectives." 